\title{
Obra ensina a analisar narrativas
}

DOI $10.1590 / 1809-5844201418$

\section{Monica Martinez}

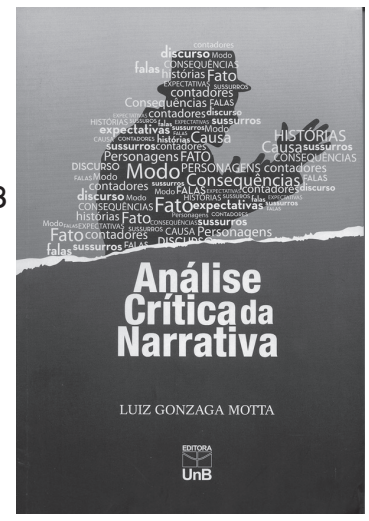

MOTTA, Luiz Gonzaga. Análise Crítica da Narrativa. Brasília: Editora Universidade de Brasília, 2013. 254 p

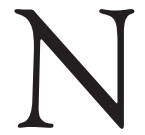

a apresentação do livro Análise Crítica da Narrativa, o docente Luiz Gonzaga Motta lembra que a primeira versão da obra foi feita anos atrás, quando lecionava a disciplina Leitura dos Meios de Comunicação na Universidade de Brasília (UnB). Ainda que ele atualmente seja professor visitante do Programa de Pós-Graduação em Jornalismo da Universidade Federal de Santa Catarina (UFSC), o dado serve para lembrar que Motta e UnB estão como o pão para manteiga (fique aqui à vontade para escolher seu par perfeito preferido), uma vez que o jornalista, formado pela Universidade Federal de Minas Gerais (1968), fez parte do quadro docente da Faculdade de Comunicação da Universidade de Brasília de 1969 a 2013 - excetuando-se um breve afastamento voluntário da instituição no período de 1982 a 1985. E, como se sabe, em Brasília - o centro político mor

\footnotetext{
* Professora do Programa de Pós-Graduação em Comunicação e Cultura da Universidade Sorocaba (UNISO), Sorocaba-SP. E-mail: monica. martinez@prof.uniso.br
} 
brasileiro -, as reflexões sobre mídia e poder são parte integrante do cotidiano dos pensadores comunicacionais.

A UnB está no DNA do pesquisador - aliás com bolsa de produtividade do $\mathrm{CNPq}$, onde desenvolve com apoio do órgão o projeto de pesquisa A construção política de uma identidade nacional na narrativa noticiosa da mídia brasileira. Da mesma forma, está também a pesquisa empírica pela qual ele se notabiliza. Nesta pesquisa apoiada pelo CNPq, por exemplo, por meio de análise quantitativa empírica, Motta compara a representação social do Brasil que emana da cobertura jornalística de dois jornais de referência nacional, em dois períodos distintos: os oito anos de governo FHC (1994-2001) e os oito anos do governo Lula (2002-2010). Esta postura empírica faz sentido ao se olhar o currículo do docente, entranhado nos saberes da comunidade científica anglo-saxã, afinal ele é mestre em Jornalismo pela Indiana University (1973) e doutor em Comunicação de Massa pela University of Wisconsin em Madison (1977). Já os saberes latinos são evocados no pós-doutorado pela Universidade Autónoma de Barcelona (2002/3).

Neste cenário, onde vida e obra se mesclam, Análise Crítica da Narrativa é uma obra bem-vinda para quem se dedica aos estudos das narrativas contemporâneas. $\mathrm{Na}$ verdade, o livro fez o bom caminho da prática à teoria, uma vez que foi concebido a partir dos textos que o autor utilizava para ministrar a disciplina Leitura dos Meios de Comunicação.

Ao longo dos anos, o conteúdo foi aperfeiçoado até chegar à versão atual, uma das vencedoras de um edital de publicação de livros da Editora UnB. Mas duas coisas se mantiveram inalteradas. A primeira é a constatação de que "a narrativa é um modo de expressão universal, que atravessa o jornalismo, o cinema, a telenovela, a fotografia, a publicidade, o conteúdo das novas mídias etc.” (MOTTA, 2013, p.9). A segunda é a premissa de uma obra que prima pela aplicação, pela usabilidade. Como ele diz: "Manteve-se no texto atual o propósito original: oferecer um quase manual que destacasse a importância da narrativa como processo universal de constituição da realidade (ficcional ou fáti- 
ca) e oferecesse aos iniciantes procedimentos práticas de análise empírica" (MOTTA, 2013, p.10).

A obra é dividida em duas partes. A primeira contém os capítulos que tratam de teoria. Já a segunda contém a metodologia de análise. $\bigcirc$ terceiro capítulo, por exemplo, ressalta a onipresença das narrativas na mídia contemporânea. Neste sentido, seu autor é um dos poucos a questionar a afirmação do pensador alemão Walter Benjamim (1892-1940) de que a arte da narrativa estava em vias de extinção. Em estudo que realizei sobre os artigos apresentados sobre Benjamim durante os dez anos de encontros no SBPJor, Motta foi o único que ousou discordar desta premissa hegemônica na área.

Duas observações que poderiam aprimorar uma nova edição da obra. Como se propõe a ser um manual, o livro ficaria mais completo se contivesse um capítulo com um estudo de caso. Além disto, ao final da obra, Motta divide a bibliografia em três níveis (iniciantes, intermediários e avançado). A princípio uma boa ideia, este recurso pode dificultar a busca pelas referências.

Apesar de a obra se destinar prioritariamente aos alunos de Comunicação, possui alcance mais amplo, sendo útil também em áreas como Literatura, Antropologia, Sociologia, Psicologia, História, entre outras. Afinal, na introdução, Motta define o ser humano como Homo Narrans. Neste sentido, o que parece definir nossa espécie é justamente seu potencial de viver de narração em narração. 